IRA-International Journal of Management \& Social Sciences

ISSN 2455-2267; Vol.04, Issue 02 (2016)

Pg. no. 394-416

Institute of Research Advances

http://research-advances.org/index.php/RAJMSS

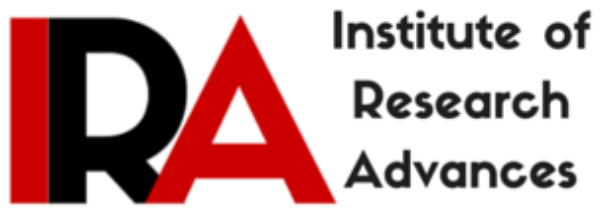

\title{
Education and Poverty Relationship in Punjab
}

\author{
${ }^{1}$ Dr. Maninder S. Sarkaria \\ Deputy State Project Director, \\ RMSA, Punjab, India.
}

\section{${ }^{2}$ Shiwani}

Assistant Professor, S.G.A.D. College,

Khadur Sahib, Tarn -Taran (Punjab), India.

Type of Review: Peer Reviewed.

DOI: http://dx.doi.org/10.21013/jmss.v4.n2.p9

\section{How to cite this paper:}

Sarkaria, M., \& Sharma, S. (2016). Education and Poverty Relationship in Punjab. IRA-International Journal of Management \& Social Sciences (ISSN 2455-2267), 4(2), 394-416. doi:http://dx.doi.org/10.21013/jmss.v4.n2.p9

(C) Institute of Research Advances

(cc) EY-NC

This work is licensed under a Creative Commons Attribution-Non Commercial 4.0 International License subject to proper citation to the publication source of the work.

Disclaimer: The scholarly papers as reviewed and published by the Institute of Research Advances (IRA) are the views and opinions of their respective authors and are not the views or opinions of the IRA. The IRA disclaims of any harm or loss caused due to the published content to any party. 


\section{ABSTRACT}

As education is being increasingly promulgated as an effective tool to reduce poverty, it is pivotal to evaluate the impact of different levels of education on poverty. This chapter analyzes the relationship between education and poverty in Punjab, using data from the primary survey of 1520 households collected over 2008-2010 from rural and urban habitations. Analysis has been done at the household as well as the individual level. Apart from making simple comparisons between standard of living, income and education level, logistic regression has been employed to sort out the determinants of poverty.

Standard of living and PCI are positively associated with education level at the household as well as the individual level, implying improvement in educational attainments reduces the likelihood of being poor. The results of logistic regression are in line with the generally accepted theory that educational attainment is critical in declining the incidence of poverty and should be given due consideration in implementing poverty alleviation programs. As one would expect, experience is negatively related with poverty status.
\end{abstract}

Key words: Education, poverty, poverty reduction, gender, occupation, Punjab, logistic.

\title{
1.1 Introduction
}

Overview of literature on relations between educational progress and social development reveals that education is a significant factor of social development of a country. However, there is dearth of comprehensive studies on such relations in India in general and in her states in particular. Studies conducted at micro level and with more disaggregate data provide deeper insights and can guide to make better and effective policies. India is a Poverty stricken country estimated to have a third of the world's poor. As per the World Bank estimates, four-fifth of India's population live on less than $2 \$$ a day in $2005^{1}$. As per an estimate of the World Bank in 2005 more than 41 percent of India is living below the international poverty line of US\$ 1.25 a day ( $₹ 21.6$ a day in urban areas and $₹ 14.3$ in rural areas), it has come down from 60 percent in $1981^{2}$. And according to the 2011 estimates of the World Bank, 30 percent of the people of India live on less than US\$ 1.25 a day. ${ }^{3}$

The World Bank has revised the global poverty line from $\$ 1.25$ a day to $\$ 1.90$ a day (approximately Rs. 130). The World Bank's recently released data shows that only 12.4 per cent of India's population was poor in 2011-12, considering an expenditure cut-off of $\$ 1.9$ a person a day on purchasing power parity (PPP) terms. ${ }^{4}$

As per the estimates of Planning Commission of India, 21.6 percent population was below poverty line in 2009-10, however, the below poverty line figure presented in parliament (on 21-3-2012) estimated by planning commission using Tendulkar methodology is 29.8 percent in the year 2009-10. As per the annual

\footnotetext{
${ }^{1} \wedge$ "Poverty data: A supplement to World Development Indicators 2008". World Bank. December 2008. http://siteresources.worldbank.org/DATASTATISTICS/Resources/WDI08supplement1216.pdf. Retrieved 7-52012. and "World Bank's new poverty norms find larger number of poor in India". The Hindu (Chennai). 200808-28. http://www.hindu.com/2008/08/28/stories/2008082856061300.htm. Retrieved 7-5-12.

2 "New Global Poverty Estimates - What it means for India". World Bank. http://www.worldbank.org.in/WBSITE/EXTERNAL/COUNTRIES/SOUTHASIAEXT/INDIAEXTN/0,,contentMDK:218 80725 pagePK:141137 piPK:141127 theSitePK:295584,00.html. Quoted on http://en.wikipedia.org/wiki/Poverty_in_India\#cite_note-WB_Poverty-1\#cite_note-WB_Poverty-1. Retrieved on 26-2-2011.

${ }^{3}$ Global Monitoring Report 2014/2015: Ending Poverty and Sharing Prosperity. A joint publication of World Bank Group and International Monetary Fund. The World Bank 2015.

${ }^{4}$ This has been arrived at based on an average of the national poverty lines of 15 poorest economies of the world. The poverty lines were converted from local currency into U.S. dollars using the new 2011 Purchasing Power Parity (PPP) data (Vargas Da Cruz, Marcio Jose; Foster, James E.-000062952; Quillin, Bryce Ramsey; Schellekens, Philip. 2015. Ending extreme poverty and sharing prosperity: progress and policies. Policy Research Note; PRN/15/03. Washington, D.C.: World Bank Group. http://documents.worldbank.org/curated/en/2015/12/25666216/ending-extreme-poverty-sharingprosperity-progress-policies accessed on 23-4-2016.
} 
report of Reserve Bank of India (2012) 21.96 percent persons are below poverty line in India. ${ }^{5}$ More than 27 percent of the population in India was living below the poverty line in 2004-05 while this percentage was more than 35 percent in 1993-94 and more than 51 percent in 1977-78.

Punjab had the lowest poverty rate in India at 6.16\% (1999-2000 figures), and won the best state performance award, based on statistical data compiled by the Government of India. The Poverty rate in Punjab was 20.9 percent and 15.9 percent in 2004-05 and 2009-10 respectively, while only 8.26 percent of the total population is below the poverty line in Punjab in 2011-12. ${ }^{7}$ Punjab recorded substantial decline in poverty over the period 2004-05 to 2011-12.

It is well established that investment in education and human capital formation are essential for economic growth and poverty reduction. The inter-relationship between education and poverty is explained through two ways. First, investment in education enhances the skills and productivity of poor households, which lead to enhanced wage level as well as the overall welfare of the population. Secondly, poverty may act as major impediment to educational attainment; which may be viewed from three perspectives. (a.) From the resource-side poverty may handicap the access to learning and other pedagogic materials (Awan et al. 2008). (b.) Poverty may generate social pressure which adversely affects the mindset of poor students (Njong 2010) and, (c.) When poverty grabs an institution it deteriorates the teaching standards (Bramley and Karley 2005).

Mathur and Mamgain (2002) have examined the impact of technical education (TE) and general education (GE) on the socio-economic development of India. The socio-economic development in their study consists of four dimensions viz. per capita state income (PCI), non-agricultural level of development (NONAG), reduction in the incidence of poverty (POV) over time, and reduction in the incidence of unemployment (UNEMP).

Both, the TE as well as the GE have shown strong positive relationships with PCI and NONAG. The impact of TE on PCI and NONAG is much stronger than that of GE. The correlations of TE as well as that of GE with POV are found to be strong and negative. However, Contrary to expectations, both, the TE and the GE, by and large, are found to be associated positively with UNEMP (but at low level of significance). They attribute this unexpected association to, inter alia, inadequate expansion of demand in the productive sectors of the economy.

Tilak (2001) has reviewed the track of educational development in Asian countries in the context of changing socio-economic and political environment. He has shown that expansion of education is positively and highly correlated with socio-economic development. On the basis of his comprehensive review of empirical researches undertaken in Asian countries, he has provided the following tentative generalizations regarding the impact of education on development:

Education, inter alia, contributes significantly:

-to expedite economic growth and the returns to education are not less than those which come from investment in physical capital; to enhance the productivity of work force; in reducing poverty; in improving income distribution; in reducing fertility rate, population growth, child/infant mortality rate etc. and in improving other basic needs.

Based on data from household survey, both Njong (2010) in Cameroon and Awan et al. (2011) in Pakistan estimated the impact of education on poverty reduction. In both the studies the logistic regression results supports the generally accepted theory that educational attainment is a critical determinant of the incidence of poverty. The inverse relationship between education attainment and poverty implies that higher the educational achievement and lower is the likelihood of an individual to be poor. The attainment of education enhances the earning potential of individuals and consequently, the increased earnings definitely help poor persons to be out of poverty. This way higher level of education would be increasingly effective

\footnotetext{
5 "Number and Percentage of Population Below Poverty Line", Reserve Bank of India, 2012. www.rbi.org.in retrieved on 23-4-2016; and "Press Note on Poverty Estimates, 2011-12", Planning Commission, Govt. of India, July 2013. Planningcommission.nic.in retrieved on 23-4-2016.

6 Planning Commission (2007), Poverty estimates for 2004-05, Government of India, March 2007. Retrieved on 26-2-2011 from http://en.wikipedia.org/wiki/Poverty_in_India\#cite_note-Poverty_estimates_for_2004-052\#cite_note-Poverty_estimates_for_2004-05-2 .

${ }^{7}$ Planningcommission.nic.in.
} 
in poverty reduction. Both these studies also reveal that women face more constraints in pulling themselves out of poverty as compared to men due to unequal educational and employment opportunities. Okojie (2002) used the data of National Consumer Expenditure Survey of 1980, 1985, 1992 and 1996 to examine the linkages between gender of household, education and poverty of household in Nigeria. He found that in 1985 poverty was higher in male-headed households as compared to female-headed households and in 1996 poverty was same in both male and female-headed households. But in 1992 poverty was higher in female headed households than male-headed households. His results also showed that the female-headed households experienced lower poverty but inequality was higher among them. Results of multivariate analysis showed that poverty in female-headed households was greater than maleheaded households, and with high level of education, the likelihood of households being poor was decreased. He points out that majority of poverty alleviation programs does not target the women and stresses the need to mainstream women into poverty alleviation programs.

Evidence from West Africa also suggests that poverty significantly contributes in gender inequality in access to education (Okojie, 2002). Siddique (1998) examined the gender issues in poverty alleviation in Bangladesh. The study confirms inverse correlation between the number of children born by women and level of education of these women. He reveals that the level of women participation in education, employment and other socio-economic and political activities was also very low. He points out that alleviation of poverty is not possible without empowering women by educating them and recommends that women should be imparted vocational education for helping them alleviate poverty.

Ahmad et al (2005) investigated the relationship between inequality in the access to secondary education and poverty in Bangladesh. On the basis of household data from 60 villages, they confirmed inequality in the access to education at post primary level in Bangladesh. The marginal return for upper secondary and primary level of education was found higher than that for lower secondary education. The association between poverty and low education was found to be positive. Further, school participation rates are found to be affected by the household's income status and also by the education level of father and mother. Majority of the poor are in rural areas. Regression results reveal that the poor in the rural areas have low income, low education, high fertility and low investment in education. Poverty has negative impact on the education of the poor.

Using logit regression analysis on primary data sets, Chaudhry and Rahman (2009) examined the impact of gender inequality in education on rural poverty in Pakistan. Their study reveals that gender inequality in education had adverse impact on rural poverty. Their findings suggest that female-male enrolment ratio, female-male literacy ratio, Female-male ratio of total years of schooling, female-male ratio of earners and education of household head have significant negative impact on rural poverty. Further, household size and female-male ratio have strong positive association with the probability of poverty. From the inverse relation between variables of gender inequality in education and rural poverty, they infer that education provides more employment opportunities and reduces poverty in developing countries like Pakistan.

On the basis of secondary data, Arif et al. (1999) sought to determine the impact of poverty on primary school enrolment in Pakistan. By using logit technique, they found that the impact of poverty on male and female enrolment was alike but the effect was different as regards income. The boy's enrolment in school was not affected by income while girl's chances of attending school depended on the availability of additional financial resources. They also found out that primary school enrolment was comparatively higher by 23 percent in urban areas as compared to 49 percent in rural areas and the negative effect of poverty on primary enrolment of girls in rural areas was greater than in the urban areas.

Chaudhry (2009) explore factors affecting rural poverty in Southern Punjab of Pakistan and found that alleviation of poverty is possible by lowering the household size and dependency ratio, improving education, increasing female labor participation. Results of Logit regression models indicate that as dependency level and household size increase the likelihood of being poor enhances. Education has significant negative relationship with poverty.

It is well documented in the literature that education has negative association with poverty. Higher the educational attainment level of the population, the lesser would be the number of poor persons however measured because education enhances knowledge and create skills leading to higher wages (Tilak, 1994). In this backdrop, using primary data collected through the field survey, this chapter studies the relationship between education and poverty in Punjab. This approach is specifically relevant in evaluating the impact of different levels of education on poverty at individual and household level in Punjab. 


\subsection{Objectives, Scope and Methodology}

\subsubsection{The Objectives}

Major objective of this chapter is to examine the relationship between education and poverty. The specific objectives of this study are listed as below:

1. To analyze the association of education and poverty in Punjab.

2. To study the patterns of poverty vis-à-vis different education levels as divided into different types of occupations across rural and urban areas.

3. To estimate the impact of different levels of education on poverty.

\subsubsection{The Coverage and Scope of the Study}

To explore the relationship between education and poverty, the analyses have been carried out at individual and household level. As data at the individual and household level are not available from secondary sources, we conducted an extensive survey of all the 19 districts $^{8}$ of the state to collect data on education and income and other related variables like education, employment status, household expenditure, age, experience, gender, income, capital base, quality of education, occupation of the family, etc.

\subsubsection{Formation of Sample for Primary Survey}

Our sample for primary survey consists of 1520 households (380 from urban, 380 from semi-urban and 760 from rural habitations $)^{9}$. However, as the poverty line data was not available separately for semi-urban population we merged semi-urban data with urban data. Thus, unlike in other chapters, analysis in this chapter has been done across two types habitations i.e. Urban and Rural.

\section{The Sample}

\begin{tabular}{|c|c|c|c|c|}
\hline Type of Habitation & Number of & \multicolumn{3}{|c|}{ Number of Persons } \\
\cline { 3 - 5 } & Households & $\mathrm{M}$ & $\mathrm{F}$ & $\mathrm{T}$ \\
\hline Urban & 760 & 1976 & 1774 & 3750 \\
\hline Rural & 760 & 2261 & 1985 & 4246 \\
\hline Total & 1520 & 4237 & 3759 & 7996 \\
\hline
\end{tabular}

Above Table contains gender-wise and habitation-wise break-up of the sample. In all we gathered information for 7996 individuals residing in 1520 households. Of the 7996 persons, 4237 are males and 3759 are females. Habitation-wise 3750 person lives in urban habitations while 4246 resides in rural areas.

\subsubsection{Data Base}

This study is based on primary data. The information collected from the sample households through primary survey includes particulars of family members, sex, marital status, age, education, occupation, income, assets, capital base, various facilities in the household, expenditure on food as well as non-food items, etc.

\subsubsection{Data Analysis}

To make sense of the data and have insights into the relationships between education \& poverty, we have analyzed data in multiple modes ranging from simple comparison to sophisticated analysis through multivariate statistical techniques. To sort out the strength and direction of relationships between education and poverty, data have been analyzed by employing logistic regression technique. Statistical analyses are performed using MedCalc for Windows, version 11.6.1.0 (MedCalc Software, Mariakerke, Belgium MedCalc Version 11.6.1.0.

\subsection{The Variables}

\footnotetext{
${ }^{8}$ There were 19 districts in Punjab when this study was initiated. With the coming up of three new districts, number of districts in Punjab have now increased to 22.

${ }^{9}$ The procedure of sampling is detailed in Chapter 1.
} 


\subsubsection{Poverty and Its Measurement}

Poverty is the lack of basic human needs, such as clean drinking water, nutrition, health care, education, clothing and shelter, because of the inability to afford them ${ }^{10}$. There are broadly two concepts of poverty viz. the relative poverty and absolute poverty. While relative poverty refers to the condition of having fewer resources or less income than others within a society or country, or compared to worldwide averages, absolute poverty is defined in terms of the minimal requirements necessary to afford minimal standards of food, clothing, health care and shelter ${ }^{11}$. In India the discussion of poverty among academicians is focused largely on absolute poverty. The poverty line is usually determined by finding the minimum expenditure that an average human adult make in one year to maintain a tolerable life. As food is the most basic requirement, thus, poverty line is drawn on the basis of a minimum necessary nutritional standard expressed in terms of calories per day. In India, the minimum calories intake of a person has been put at 2,400 in rural areas and 2,100 in urban areas. The calorie intake is converted into a monitory measure of poverty by calculating the cost of minimum consumption requirements of food providing the minimum calories. We have used the criterion of monthly per capita consumption expenditure below ₹ 897 for rural areas and ₹ 1060 for urban areas to determine the poverty level. We have used the poverty figure computed by planning commission. Planning Commission computed poverty threshold level to be ₹ 543.51 for rural area and ₹ 642.51 for urban area in 2004-05. We updated rural threshold level of poverty with CPI for agricultural workers and that of urban area with CPI of industrial workers in Punjab for the year 2008-09.

As it is a difficult task to accurately collect data on household income, data on household monthly per capita expenditure (MPCE) - a close proxy for household income is used. The profile of household consumer expenditure is a meaningful indicator for level of living. In the present survey, data on household consumer expenditure was collected through a separate schedule. MPCE has been computed, separately for rural and urban areas, and for each of the 19 districts surveyed for this study. The worksheet contained 24 different components of household consumer expenditure. Depending upon the type of item, either of the two reference periods viz. 30 days and 365 days, was used to record consumption of different groups of items.

\subsubsection{Other Variables and their Measurement}

Meaning, definition and measurement of education and various variables relating to education are the same as contained and used in Chapter 5 entitled, "Education and Income Relationship in Punjab" of this report. They are being simply listed here.

Education: Categorized into 7 levels in terms of number of years put in educational institutions, viz. 0, 1$5,6-8,9-10,11-12,13-15,15^{+}$.

Gender: Male and Female.

Types of Habitation: Rural and Urban.

Experience: On the job experience in number of years.

Occupation: Agriculture and/or dairy, wage worker, own work and regular service/work.

Income: Household income includes income from all sources including family business, salary/wages of members of the household, interest income, pension, remittances from India and abroad, rent or return from family property or assets, etc. For the individual level analysis, only that income has been considered which can be ascribed to the efforts, competence, skill and education of the person.

Employment Status: Fully employed, Under-employed and Unemployed.

Sector of Employment: Government job or private work.

\subsection{Findings}

\footnotetext{
${ }^{10}$ Encarta Poverty definition. Encarta.msn.com. http://encarta.msn.com/encnet/features/dictionary/DictionaryResults.aspx?lextype=3\&search=poverty. Retrieved 2010-10-24

${ }^{11}$ http://dictionary.babylon.com/absolute\%20poverty/
} 
This part of the chapter contains the analysis of data on education and poverty relationships followed by interpretation

and ends with conclusion and implications.

\subsubsection{Education and Poverty}

Relationship between Education and Poverty: Table 1 and Figure 1 reveal that per capita MPCE and PCI of the households increase consistently with the increase in educational attainments. For illiterate households MPCE (proxy for standard of living) is the lowest while it is the highest for the households with the highest level of education. The same trend is seen as regards PCI.

\section{Table 1}

Levels of Education, MPCE and PCI in Punjab

(Employed and Under-employed above 15)

\begin{tabular}{|l|l|l|l|l|l|}
\hline Education & $\mathrm{n}$ & MPCE & \% of Total & PCI & \% of Total \\
\hline 0 & 542 & 1084.24 & 7.5 & 2142.55 & 6.2 \\
\hline 5 & 271 & 1190.9 & 8.2 & 2192.37 & 6.4 \\
\hline 8 & 396 & 1398.27 & 9.7 & 2926.02 & 8.5 \\
\hline 10 & 602 & 1915.6 & 13.3 & 4012.5 & 11.7 \\
\hline 12 & 412 & 2289.3 & 15.8 & 5327.66 & 15.5 \\
\hline 15 & 270 & 3118.6 & 21.6 & 7369 & 21.4 \\
\hline $15+$ & 351 & 3450.75 & 23.9 & 10447.93 & 30.3 \\
\hline Total & 2844 & 14447.66 & 100 & 34418.03 & 100 \\
\hline
\end{tabular}

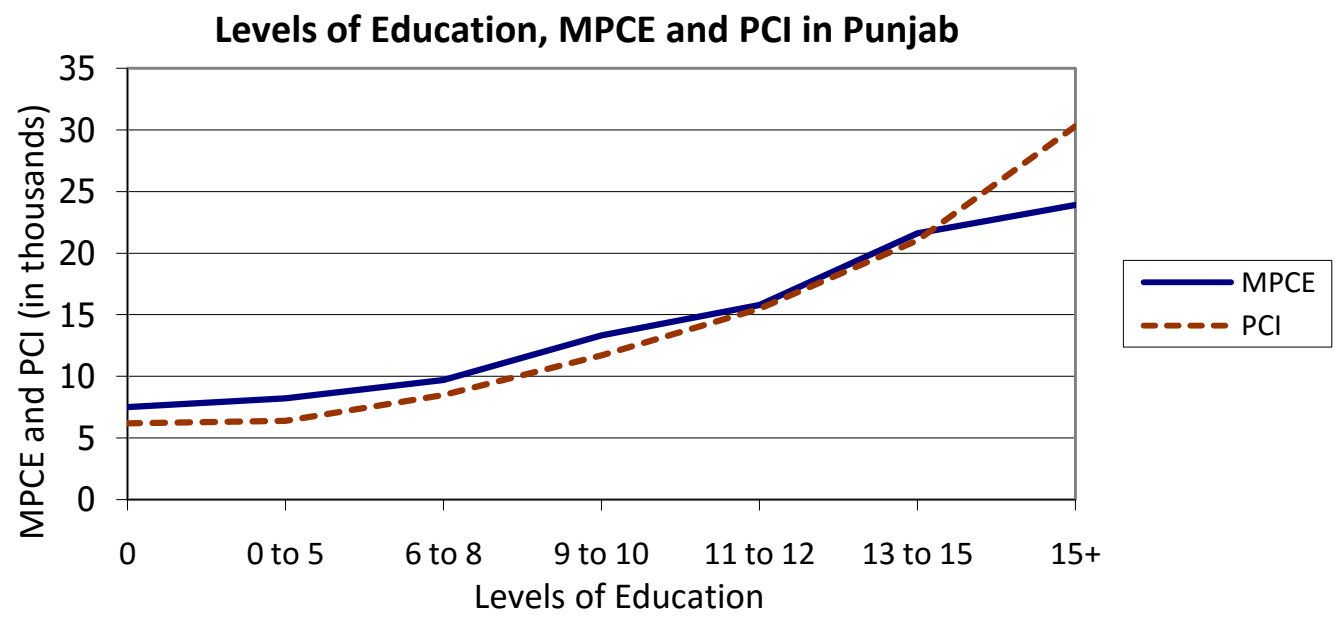

Figure 1 
IRA-International Journal of Management \& Social Sciences

Table 2

Occupation-wise Levels of Education, MPCE and PCI of Households

\begin{tabular}{|c|c|c|c|c|c|c|c|c|c|c|c|c|c|c|c|c|c|c|c|c|c|}
\hline \multirow{2}{*}{ 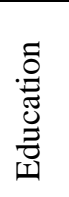 } & \multicolumn{5}{|c|}{$\mathrm{HHO}_{\text {Agriculture }}$} & \multicolumn{5}{|c|}{$\mathrm{HHO}_{\text {Wage Work }}$} & \multicolumn{5}{|c|}{$\mathrm{HHO}_{\text {Own Work }}$} & \multicolumn{5}{|c|}{$\mathrm{HHO}_{\text {Service }}$} & \multirow{2}{*}{ 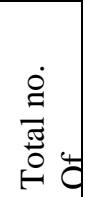 } \\
\hline & $\begin{array}{l}\text { U } \\
\sum \\
\sum\end{array}$ & 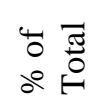 & $\bar{U}$ & 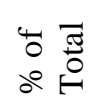 & $=$ & $\begin{array}{l}\text { U } \\
\sum \\
\sum\end{array}$ & 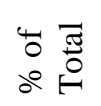 & $\bar{U}$ & $\begin{array}{l}山 \\
0 \\
0 \\
0\end{array}$ & $=$ & $\begin{array}{l}\text { U } \\
\sum \\
\sum\end{array}$ & $\begin{array}{l}\text { 山ै } \overline{0} \\
\text { oீ }\end{array}$ & $\bar{Q}$ & 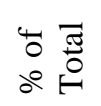 & $=$ & $\begin{array}{l}\text { U1 } \\
\sum \\
\sum\end{array}$ & 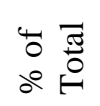 & $\vec{Q}$ & $\begin{array}{l}山 \\
0 \\
0 \\
0\end{array}$ & $=$ & \\
\hline 0 & 1831.1 & 11.14 & 4488.65 & 9.25 & 108 & 752.2 & 13.17 & 1206.31 & 15.03 & 306 & 1177.3 & 7.95 & 1965.31 & 6.58 & 71 & 1335.59 & 8.52 & 2944.25 & 8.15 & 57 & 542 \\
\hline 5 & 1761.5 & 10.72 & 4875.11 & 10.05 & 46 & 789.1 & 13.82 & 1041.01 & 12.97 & 111 & 1272.5 & 8.60 & 2003.13 & 6.71 & 80 & 1539.1 & 9.81 & 2766.91 & 7.66 & 34 & 271 \\
\hline 10 & 2311.7 & 14.07 & 6201.43 & 12.78 & 134 & 885.9 & 15.52 & 1256.19 & 15.65 & 71 & 2008.8 & 13.57 & 3503.64 & 11.74 & 217 & 1914.4 & 12.21 & 4083.64 & 11.31 & 180 & 602 \\
\hline 12 & 2221.7 & 13.52 & 6937.76 & 14.30 & 89 & 1047.1 & 18.34 & 1888.27 & 23.53 & 30 & 2422.2 & 16.36 & 4956.91 & 16.61 & 131 & 2448.9 & 15.61 & 5453.9 & 15.10 & 162 & 412 \\
\hline 15 & 3130.5 & 19.05 & 10244.23 & 21.12 & 43 & 1370.3 & 24.00 & 1435 & 17.88 & 2 & 3013.8 & 20.36 & 6247.57 & 20.93 & 74 & 3189.7 & 20.34 & 7178.4 & 19.88 & 151 & 270 \\
\hline $15+$ & 3115.4 & 18.95 & 9869.19 & 20.34 & 24 & - & & - & - & - & 3610 & 24.39 & 8877.22 & 29.74 & 54 & 3705.88 & 23.63 & 10829.27 & 29.99 & 273 & 351 \\
\hline
\end{tabular}

Table 2 provides information on average monthly per capita expenditure (MPCE) and per capita income (PCI) of households as per different levels of education ranging from illiteracy to post graduation across different occupations. Evidently, by and large, as the level of education rises so does the standard of living and PCI. The positive association between and among level of education, MPCE and PCI is also seen across all the three types of occupations.

Table 3 shows the association between MPCE and PCI of employed individuals across different types of occupations. By and large, MPCE and PCI of individuals increase with the increase in educational attainments. But in case of Agriculture and Wage work occupation PCI has declined for individuals with $15^{+}$education in comparison to individuals with 13-15 education. 
IRA-International Journal of Management \& Social Sciences

Table 3

Occupation-wise Levels of Education, MPCE and PCI of Individuals: Punjab

\begin{tabular}{|c|c|c|c|c|c|c|c|c|c|c|c|c|c|c|c|c|c|c|c|c|c|}
\hline \multirow{2}{*}{ 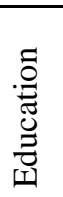 } & \multicolumn{5}{|c|}{ Ind. $\mathrm{O}_{\text {Agriculture }}$} & \multicolumn{5}{|c|}{ Ind. $\mathrm{O}_{\text {Wage Work }}$} & \multicolumn{5}{|c|}{ Ind. $\mathrm{O}_{\text {Own Work }}$} & \multicolumn{5}{|c|}{ Ind. $\mathrm{O}_{\text {Service }}$} & \multirow{2}{*}{$\begin{array}{l}\dot{g} \\
\stackrel{\tilde{J}}{0} \\
\stackrel{0}{0}\end{array}$} \\
\hline & 仓 & 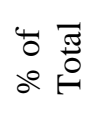 & U & 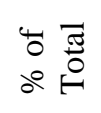 & $=$ & $\begin{array}{l}\text { U1 } \\
\sum\end{array}$ & 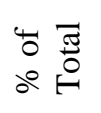 & 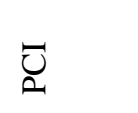 & 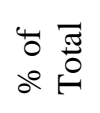 & $=$ & 巳 & $\begin{array}{ll}4 & 7 \\
0 & 0 \\
0 & 0\end{array}$ & 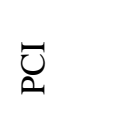 & 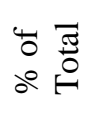 & $=$ & $\begin{array}{l}\text { Un } \\
\sum\end{array}$ & $\begin{array}{l}\text { पू } \\
0 \\
0\end{array}$ & $\Xi$ & $\begin{array}{l}4 \pi \\
0 \\
0\end{array}$ & $=$ & \\
\hline 0 & 1790.9 & $\begin{array}{r}10.1 \\
9\end{array}$ & 4416.33 & 9.08 & $\begin{array}{l}11 \\
4\end{array}$ & 770.1 & 11.93 & 1253.58 & 12.44 & 304 & $\begin{array}{l}1321 . \\
4\end{array}$ & 9.10 & 2276.52 & 7.79 & 62 & $\begin{array}{l}1087.9 \\
9\end{array}$ & 7.42 & 1986.58 & 5.90 & 62 & 542 \\
\hline 5 & 1800.9 & $\begin{array}{r}10.2 \\
5\end{array}$ & 4993 & 10.26 & 48 & 779.8 & 12.09 & 1067.18 & 10.59 & 94 & $\begin{array}{l}1251 . \\
1\end{array}$ & 8.61 & $\begin{array}{l}1981.7 \\
4\end{array}$ & 6.78 & 87 & 1289.2 & 8.79 & 1946.24 & 5.78 & 42 & 271 \\
\hline 8 & 2144.4 & $\begin{array}{r}12.2 \\
1\end{array}$ & 6168.76 & 12.68 & 80 & 904.4 & 14.02 & 1234.78 & 12.25 & 100 & $\begin{array}{l}1346 . \\
7\end{array}$ & 9.26 & $\begin{array}{l}2370.4 \\
8\end{array}$ & 8.12 & 123 & $\begin{array}{l}1350.2 \\
5\end{array}$ & 9.21 & 2689.83 & 8.00 & 93 & 396 \\
\hline 10 & 2525.7 & $\begin{array}{r}14.3 \\
7\end{array}$ & 6807.46 & 13.99 & $\begin{array}{l}11 \\
4\end{array}$ & 1005.2 & 15.58 & 1556.97 & 15.45 & 66 & $\begin{array}{l}1986 . \\
2\end{array}$ & $\begin{array}{r}13.6 \\
6\end{array}$ & $\begin{array}{l}3446.9 \\
1\end{array}$ & 11.80 & 233 & 1778.3 & $\begin{array}{r}12.1 \\
3\end{array}$ & 3881.41 & 11.54 & 189 & 602 \\
\hline 12 & 2273.1 & $\begin{array}{r}12.9 \\
4\end{array}$ & 7280.94 & 14.96 & 66 & 1478.6 & 22.91 & 2869.71 & 28.47 & 21 & $\begin{array}{l}2426 . \\
3\end{array}$ & $\begin{array}{r}16.6 \\
9\end{array}$ & $\begin{array}{l}4825.2 \\
0\end{array}$ & 16.52 & 143 & 2281 & $\begin{array}{r}15.5 \\
6\end{array}$ & 5297.72 & 15.75 & 182 & 412 \\
\hline 15 & 3452.4 & $\begin{array}{r}19.6 \\
5\end{array}$ & 11750.18 & 24.15 & 28 & 1514.7 & 23.47 & 2097.33 & 20.81 & 3 & 2945.4 & $\begin{array}{r}20.2 \\
6\end{array}$ & $\begin{array}{l}6679.4 \\
7\end{array}$ & 22.87 & 87 & 3187.9 & $\begin{array}{r}21.7 \\
4\end{array}$ & 7060.59 & 20.99 & 152 & 270 \\
\hline $15+$ & 3582.7 & $\begin{array}{r}20.3 \\
9\end{array}$ & 7241.6 & 14.88 & 9 & - & - & - & - & - & $\begin{array}{l}3259 . \\
3\end{array}$ & $\begin{array}{r}22.4 \\
2\end{array}$ & $\begin{array}{l}7630.4 \\
8\end{array}$ & 26.12 & 27 & $\begin{array}{l}3686.2 \\
5\end{array}$ & $\begin{array}{r}25.1 \\
5\end{array}$ & $\begin{array}{l}10781.0 \\
4\end{array}$ & 32.04 & 315 & 351 \\
\hline$\stackrel{\pi}{0}$ & $\begin{array}{l}\overrightarrow{0} \\
\stackrel{n}{n}\end{array}$ & 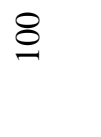 & $\begin{array}{l}\text { No } \\
\infty \\
\infty \\
\infty \\
\infty \\
+\end{array}$ & 8 & ஜे & 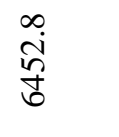 & 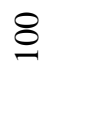 & 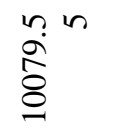 & 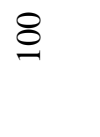 & $\begin{array}{l}\infty \\
\infty \\
\infty\end{array}$ & 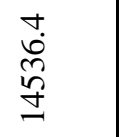 & 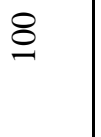 & $\begin{array}{l}\infty \\
\stackrel{\infty}{\Omega}\end{array}$ & 8 & ชู & $\begin{array}{l}\infty \\
\stackrel{0}{0} \\
0 \\
0 \\
\pm \\
\pm\end{array}$ & 8 & $\begin{array}{l}\dot{\nabla}- \\
\ddot{J} \\
\ddot{m}\end{array}$ & 8 & ஜ & 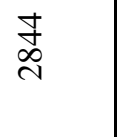 \\
\hline
\end{tabular}


Table 4 and Figure 2 show that in urban areas MPCE and PCI are increasing consistently with the increase in educational attainment.

Table 4

Levels of Education, MPCE and PCI in Urban Punjab

(Employed and Under-employed above 15)

\begin{tabular}{|l|r|r|l|r|l|}
\hline Education & MPCE & \% of Total & PCI & \% of Total & $\mathrm{n}$ \\
\hline 0 & 1114.03 & 7.09 & 1974.01 & 5.76 & 137 \\
\hline 5 & 1298.02 & 8.26 & 2107.36 & 6.15 & 111 \\
\hline 8 & 1449.72 & 9.22 & 2307.03 & 6.73 & 156 \\
\hline 10 & 1989.65 & 12.66 & 3877.34 & 11.31 & 280 \\
\hline 12 & 2654.69 & 16.89 & 5436.77 & 15.86 & 212 \\
\hline 15 & 3388.75 & 21.56 & 7339.36 & 21.40 & 178 \\
\hline $15+$ & 3826.5 & 24.34 & 11248 & 32.80 & 276 \\
\hline Total & 15721.36 & 100 & 34289.87 & 100 & 1350 \\
\hline
\end{tabular}

Levels of Education, MPCE and PCI in Urban Punjab

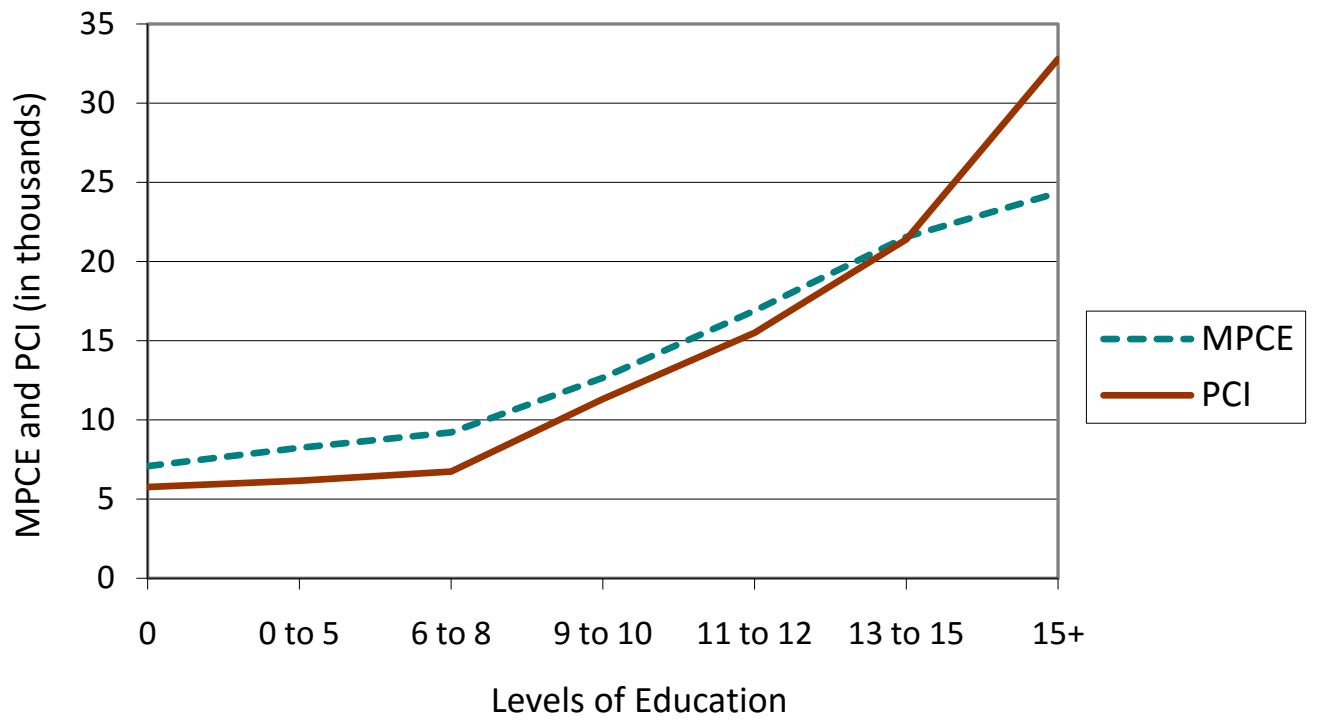

Figure 2 
IRA-International Journal of Management \& Social Sciences

Table 5

Occupation-wise Levels of Education, MPCE and PCI of Households in Urban Punjab

\begin{tabular}{|c|c|c|c|c|c|c|c|c|c|c|c|c|c|c|c|c|c|c|c|c|c|}
\hline \multirow{2}{*}{ 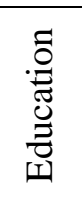 } & \multicolumn{5}{|c|}{$\mathrm{HHO}_{\text {Agriculture }}$} & \multicolumn{5}{|c|}{$\mathrm{HHO}_{\text {Wage Work }}$} & \multicolumn{5}{|c|}{$\mathrm{HHO}_{\text {Own Work }}$} & \multicolumn{5}{|c|}{$\mathrm{HHO}_{\text {Service }}$} & \multirow[b]{2}{*}{ 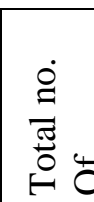 } \\
\hline & $\begin{array}{l}\text { Uు } \\
\sum \\
\Sigma\end{array}$ & 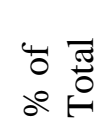 & $\bar{Q}$ & 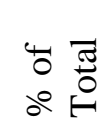 & $=$ & 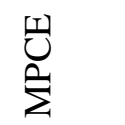 & 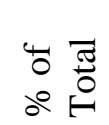 & $\bar{\Sigma}$ & 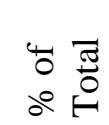 & $=$ & $\begin{array}{l}\text { Uు } \\
\stackrel{\Sigma}{\Sigma}\end{array}$ & 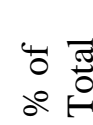 & $\bar{Q}$ & 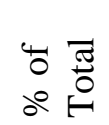 & $=$ & $\begin{array}{l}\text { U } \\
\dot{E}\end{array}$ & $\begin{array}{l}\text { U. } \bar{\pi} \\
\text { of }\end{array}$ & $\bar{Z}$ & 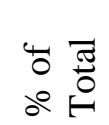 & $=$ & \\
\hline 0 & 1789.8 & 9.37 & 2940.3 & 7.50 & 7 & 925.4 & 18.50 & 1293.4 & 19.38 & 75 & 1294.5 & 8.04 & 2100.7 & 6.58 & 30 & 1427.66 & 8.71 & 3593.08 & 9.33 & 25 & 137 \\
\hline 5 & 2098.9 & 10.99 & 5402.83 & 13.77 & 6 & 845.8 & 16.91 & 1007.42 & 15.10 & 36 & 1438.1 & 8.93 & 2291.85 & 7.18 & 47 & 1520.35 & 9.28 & 2614.37 & 6.79 & 22 & 111 \\
\hline 8 & 2873.9 & 15.05 & 3970.25 & 10.12 & 8 & 1062.5 & 21.25 & 1396.85 & 20.93 & 40 & 1439.4 & 8.94 & 2402.02 & 7.52 & 57 & 1541.74 & 9.41 & 2653.83 & 6.89 & 51 & 156 \\
\hline 10 & 2176.8 & 11.40 & 5459.71 & 13.92 & 7 & 1018.5 & 20.37 & 1372.53 & 20.57 & 30 & 2217.4 & 13.77 & 3926.56 & 12.30 & 140 & 1950.22 & 11.90 & 4432.47 & 11.51 & 103 & 280 \\
\hline 12 & 2435.5 & 12.75 & 5294.25 & 13.50 & 8 & 1148.7 & 22.97 & 1602.33 & 24.01 & 9 & 2802.6 & 17.41 & 5390.97 & 16.89 & 89 & 2674.92 & 16.32 & 5811.55 & 15.09 & 106 & 212 \\
\hline 15 & 5689.2 & 29.79 & 7583.5 & 19.33 & 4 & - & - & - & - & - & 3261.1 & 20.26 & 6848.8 & 21.46 & 60 & 3375.20 & 20.59 & 7588.98 & 19.71 & 114 & 178 \\
\hline $15+$ & 2036.7 & 10.66 & 8573.0 & 21.86 & 4 & - & - & - & - & - & 3645.7 & 22.65 & 8960.26 & 28.07 & 50 & 3899.5 & 23.79 & 11812.2 & 30.68 & 222 & 276 \\
\hline$\stackrel{\bar{\Xi}}{0}$ & $\begin{array}{l}\infty \\
\stackrel{8}{8} \\
\stackrel{2}{2}\end{array}$ & $\begin{array}{l}\overline{0} \\
\dot{8}\end{array}$ & $\begin{array}{l}\infty \\
\text { तें } \\
\text { నू } \\
\text { ले }\end{array}$ & $\begin{array}{l}8 \\
8 \\
8\end{array}$ & Ұ & 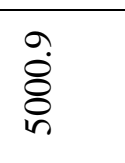 & $\begin{array}{l}8 \\
8 \\
8\end{array}$ & 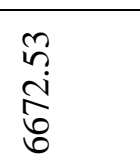 & $\begin{array}{l}8 \\
\dot{8}\end{array}$ & ‡ & $\begin{array}{l}\infty \\
\infty \\
\dot{0} \\
\stackrel{0}{0}\end{array}$ & $\begin{array}{l}8 \\
8 \\
8\end{array}$ & $\begin{array}{l}\stackrel{\overrightarrow{\vec{d}}}{\sigma} \\
\stackrel{\vec{m}}{ }\end{array}$ & $\begin{array}{l}8 \\
8 \\
8\end{array}$ & $\stackrel{\stackrel{2}{\sigma}}{\sigma}$ & $\begin{array}{l}n \\
2 \\
\infty \\
0 \\
0 \\
0\end{array}$ & $\begin{array}{l}8 \\
8 \\
8\end{array}$ & $\begin{array}{l}+\infty \\
\dot{\delta} \\
\stackrel{n}{n} \\
\infty \\
\infty\end{array}$ & $\begin{array}{l}8 \\
8 \\
8\end{array}$ & 䟢 & $\begin{array}{l}\stackrel{n}{n} \\
\end{array}$ \\
\hline
\end{tabular}

Table 5 shows the relationship between and among education level, standard of living and income of the households in urban area across different types of occupations. The MPCE and PCI are generally increasing with increase in level of education in case of the occupations Wage work, Own work and Service. However, the association between them is not showing consistent upward trend in case of agriculture in urban area. Pertinently, the number of respondents are comparatively very less in agricultural occupation in urban area. 
Table 6

Occupation-wise Levels of Education, MPCE and PCI of Individuals: Urban Punjab

\begin{tabular}{|c|c|c|c|c|c|c|c|c|c|c|c|c|c|c|c|c|c|c|c|c|c|}
\hline \multirow{2}{*}{ 总 } & \multicolumn{5}{|c|}{ Ind. $\mathrm{O}_{\text {Agriculture }}$} & \multicolumn{5}{|c|}{ Ind. $\mathrm{O}_{\text {Wage Work }}$} & \multicolumn{5}{|c|}{ Ind. $\mathrm{O}_{\text {Own Work }}$} & \multicolumn{5}{|c|}{ Ind. $\mathrm{O}_{\text {Service }}$} & \multirow{2}{*}{$\begin{array}{c}\dot{g} \\
\stackrel{\tilde{J}}{0} \\
\dot{\theta}\end{array}$} \\
\hline & $\begin{array}{l}\text { Ũ } \\
\sum\end{array}$ & $\begin{array}{l}4 \overline{0} \\
0 \\
0\end{array}$ & 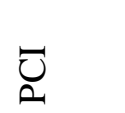 & 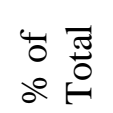 & $=$ & $\begin{array}{l}\text { Un } \\
\sum\end{array}$ & $\begin{array}{l}4 \\
0 \\
0 \\
0\end{array}$ & 己 & $\begin{array}{l}4 \pi \\
0 \\
0\end{array}$ & $=$ & $\begin{array}{l}\text { Un } \\
\sum\end{array}$ & 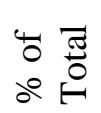 & 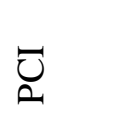 & 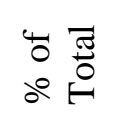 & $=$ & $\begin{array}{l}\text { Û } \\
\sum\end{array}$ & $\begin{array}{l}-\pi \\
0 \\
0\end{array}$ & 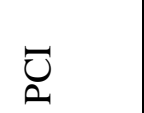 & 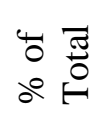 & $=$ & \\
\hline 0 & $\begin{array}{l}1711 . \\
7\end{array}$ & 8.96 & $\begin{array}{l}2814.5 \\
7\end{array}$ & 8.00 & 7 & 957.8 & $\begin{array}{r}13.9 \\
1\end{array}$ & $\begin{array}{l}1425.2 \\
2\end{array}$ & 13.60 & 72 & $\begin{array}{l}1316 . \\
0\end{array}$ & 8.34 & $\begin{array}{l}2497.8 \\
2\end{array}$ & 7.91 & 33 & $\begin{array}{l}1283.4 \\
8\end{array}$ & 8.08 & $\begin{array}{l}2627.7 \\
2\end{array}$ & 7.32 & 25 & $\begin{array}{l}13 \\
7\end{array}$ \\
\hline 5 & $\begin{array}{l}2228 . \\
8\end{array}$ & 11.67 & 5637.5 & 16.01 & 8 & 800.7 & $\begin{array}{r}11.6 \\
3\end{array}$ & $\begin{array}{l}1023.1 \\
9\end{array}$ & 9.76 & 32 & $\begin{array}{l}1385 . \\
4\end{array}$ & 8.78 & $\begin{array}{l}2229.5 \\
9\end{array}$ & 7.06 & 49 & $\begin{array}{l}1488.3 \\
6\end{array}$ & 9.37 & $\begin{array}{l}2128.4 \\
1\end{array}$ & 5.93 & 22 & $\begin{array}{l}11 \\
1\end{array}$ \\
\hline 8 & $\begin{array}{l}2873 . \\
9\end{array}$ & 15.04 & $\begin{array}{l}3970.2 \\
5\end{array}$ & 11.28 & 8 & $\begin{array}{l}1145 . \\
9\end{array}$ & $\begin{array}{r}16.6 \\
5\end{array}$ & $\begin{array}{l}1544.3 \\
1\end{array}$ & 14.74 & 32 & $\begin{array}{l}1509 . \\
1\end{array}$ & 9.57 & $\begin{array}{l}2524.0 \\
3\end{array}$ & 7.99 & 69 & $\begin{array}{l}1326.9 \\
3\end{array}$ & 8.36 & $\begin{array}{l}2224.6 \\
4\end{array}$ & 6.20 & 47 & $\begin{array}{l}15 \\
6\end{array}$ \\
\hline 10 & $\begin{array}{l}2833 . \\
8\end{array}$ & 14.83 & $\begin{array}{l}8998.8 \\
6\end{array}$ & 25.56 & 7 & 930.4 & $\begin{array}{r}13.5 \\
2\end{array}$ & $\begin{array}{l}1284.6 \\
8\end{array}$ & 12.26 & 25 & $\begin{array}{l}2190 . \\
7\end{array}$ & $\begin{array}{r}13.8 \\
9\end{array}$ & $\begin{array}{l}3818.4 \\
3\end{array}$ & 12.09 & $\begin{array}{l}15 \\
0\end{array}$ & $\begin{array}{l}1891.7 \\
7\end{array}$ & $\begin{array}{r}11.9 \\
1\end{array}$ & $\begin{array}{l}4263.0 \\
8\end{array}$ & $\begin{array}{r}11.8 \\
8\end{array}$ & 98 & $\begin{array}{l}28 \\
0\end{array}$ \\
\hline 12 & $\begin{array}{l}2739 . \\
8\end{array}$ & 14.34 & $\begin{array}{l}4924.1 \\
1\end{array}$ & 13.99 & 9 & $\begin{array}{l}1648 . \\
1\end{array}$ & $\begin{array}{r}23.9 \\
4\end{array}$ & 2932 & 27.98 & 3 & $\begin{array}{l}2777 . \\
4\end{array}$ & $\begin{array}{r}17.6 \\
1\end{array}$ & $\begin{array}{l}5321.4 \\
1\end{array}$ & 16.85 & 97 & $\begin{array}{l}2561.0 \\
4\end{array}$ & $\begin{array}{r}16.1 \\
3\end{array}$ & $\begin{array}{l}5663.1 \\
6\end{array}$ & $\begin{array}{r}15.7 \\
8\end{array}$ & $\begin{array}{l}10 \\
3\end{array}$ & $\begin{array}{l}21 \\
2\end{array}$ \\
\hline 15 & $\begin{array}{l}6716 . \\
4\end{array}$ & 35.16 & 8857.0 & 25.16 & 3 & $\begin{array}{l}1400 . \\
6\end{array}$ & $\begin{array}{r}20.3 \\
5\end{array}$ & 2271 & 21.67 & 2 & $\begin{array}{l}3181 . \\
3\end{array}$ & $\begin{array}{r}20.1 \\
7\end{array}$ & $\begin{array}{l}7266.9 \\
4\end{array}$ & 23.01 & 68 & $\begin{array}{l}3465.8 \\
8\end{array}$ & $\begin{array}{r}21.8 \\
2\end{array}$ & 7439.4 & $\begin{array}{r}20.7 \\
2\end{array}$ & $\begin{array}{l}10 \\
5\end{array}$ & $\begin{array}{l}17 \\
8\end{array}$ \\
\hline $\begin{array}{l}15 \\
+\end{array}$ & - & - & - & - & - & - & - & - & - & - & $\begin{array}{l}3413 . \\
4\end{array}$ & $\begin{array}{r}21.6 \\
4\end{array}$ & $\begin{array}{l}7928.8 \\
7\end{array}$ & 25.10 & 23 & 3864.1 & $\begin{array}{r}24.3 \\
3\end{array}$ & $\begin{array}{l}11550.3 \\
9\end{array}$ & $\begin{array}{r}32.1 \\
7\end{array}$ & $\begin{array}{l}25 \\
3\end{array}$ & $\begin{array}{l}27 \\
6\end{array}$ \\
\hline 胥 & $\begin{array}{l}\dot{J} \\
\dot{0} \\
\stackrel{0}{ }\end{array}$ & ᄋ & 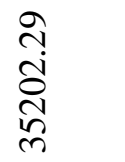 & 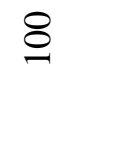 & $\stackrel{4}{\mathcal{H}}$ & $\begin{array}{l}n \\
\infty \\
\infty \\
0\end{array}$ & 8 & $\begin{array}{l}+ \\
\stackrel{0}{0} \\
\stackrel{0}{0}\end{array}$ & 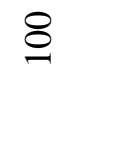 & $\underset{0}{0}$ & \begin{tabular}{l}
$m$ \\
\multirow{n}{n}{} \\
$n$
\end{tabular} & 8 & $\begin{array}{l}g \\
\dot{\sigma} \\
\infty \\
\text { m }\end{array}$ & రㅜㅇ & ஓి & $\begin{array}{l}\infty \\
\curvearrowleft \\
\infty \\
\infty \\
\curvearrowleft\end{array}$ & ○ & $\begin{array}{l}\infty \\
0 \\
\infty \\
\infty \\
\infty \\
m\end{array}$ & ᄋ & $\frac{n}{6}$ & $\begin{array}{l}\text { 음 } \\
\text { ñ }\end{array}$ \\
\hline
\end{tabular}

At the individual level, MPCE and PCI are, by and large, enhancing with rise in education level in urban Punjab, but the trend of PCI is very inconsistent in case of Agriculture and Wage work occupation and that of MPCE for Wage work occupation (see Table 6) 
Table 7

Levels of Education, MPCE and PCI in Rural Punjab (Employed and Under-employed above 15)

\begin{tabular}{|l|r|r|l|r|l|}
\hline Education & \multicolumn{1}{|l|}{ MPCE } & \multicolumn{1}{l}{$\begin{array}{l}\text { \% of } \\
\text { Total }\end{array}$} & PCI & \multicolumn{1}{l}{$\begin{array}{l}\text { of } \\
\text { Total }\end{array}$} & $\mathrm{n}$ \\
\hline 0 & 1064.7 & 8.25 & 2199.56 & 6.86 & 405 \\
\hline 5 & 1116.6 & 8.66 & 2251.34 & 7.02 & 160 \\
\hline 8 & 1364.83 & 10.58 & 3328.36 & 10.39 & 240 \\
\hline 10 & 1851.12 & 14.35 & 4130.03 & 12.89 & 322 \\
\hline 12 & 1901.89 & 14.74 & 5212 & 16.26 & 200 \\
\hline 15 & 2595.9 & 20.12 & 7426.36 & 23.17 & 92 \\
\hline $15+$ & 3003.99 & 23.29 & 7501.48 & 23.41 & 75 \\
\hline Total & 12899.03 & 100.00 & 32049.13 & 100.00 & 1494 \\
\hline
\end{tabular}

It is evident from Table 7 and Figure 3that standard of living and income of households are positively associated with level of education in rural Punjab. MPCE and PCI are increasing consistently with increase in level of education.

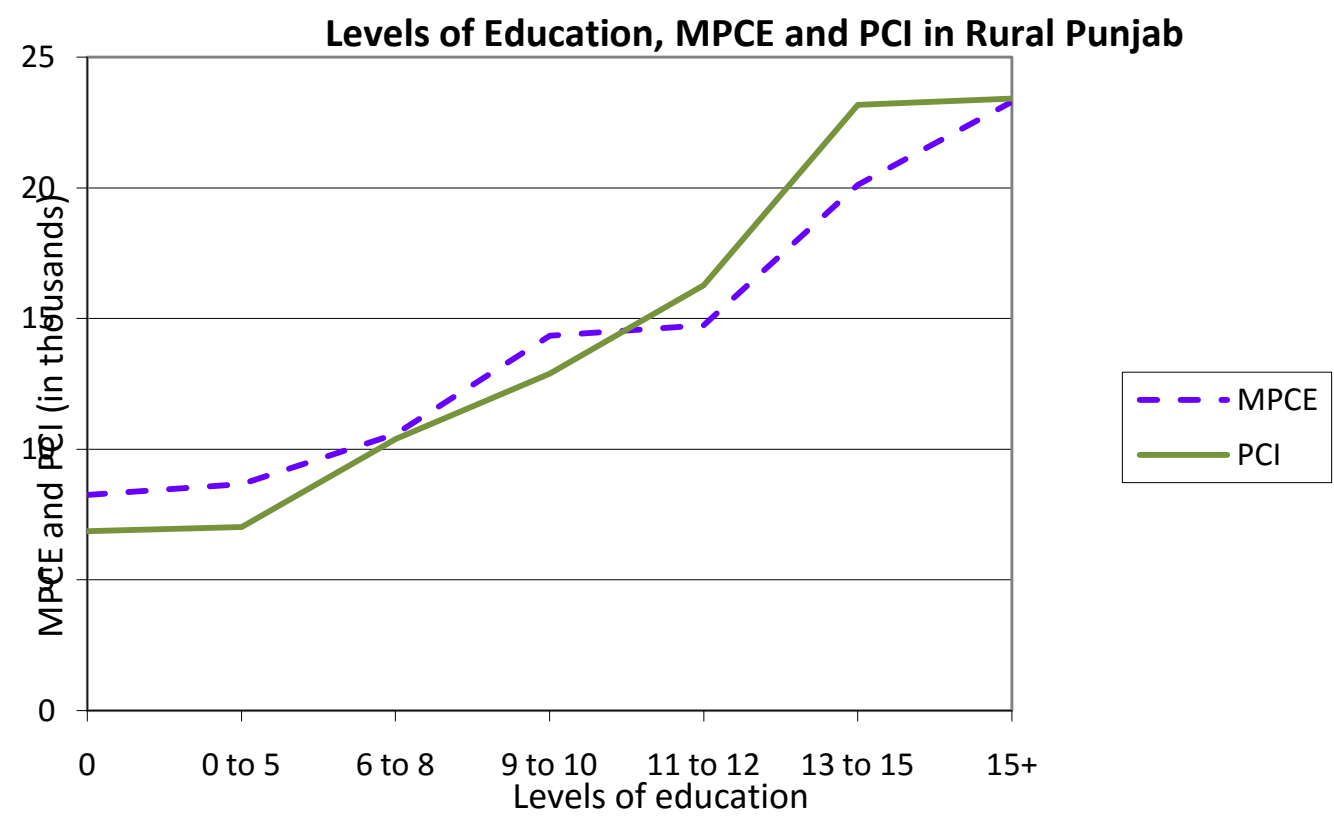

Figure 3 
Table 8

Occupation-wise Levels of Education, MPCE and PCI of Households in Rural Punjab

\begin{tabular}{|c|c|c|c|c|c|c|c|c|c|c|c|c|c|c|c|c|c|c|c|c|c|}
\hline \multirow{2}{*}{ 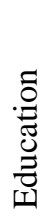 } & \multicolumn{5}{|c|}{$\mathrm{HHO}_{\text {Agriculture }}$} & \multicolumn{5}{|c|}{$\mathrm{HHO}_{\text {Wage Work }}$} & \multicolumn{5}{|c|}{$\mathrm{HHO}_{\text {Own Work }}$} & \multicolumn{5}{|c|}{$\mathrm{HHO}_{\text {Service }}$} & \multirow{2}{*}{ 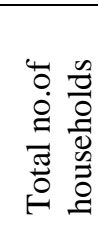 } \\
\hline & $\begin{array}{l}\text { Uు } \\
\text { 至 }\end{array}$ & 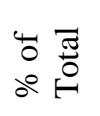 & 己 & $\begin{array}{l}4 \\
0 \\
0 \\
0\end{array}$ & $=$ & $\begin{array}{l}\text { U } \\
\sum \\
\sum\end{array}$ & 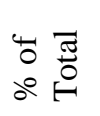 & $\bar{Q}$ & $\begin{array}{l}4 \\
0 \\
0 \\
0\end{array}$ & $=$ & $\begin{array}{l}\text { Uు } \\
\sum \\
\sum\end{array}$ & 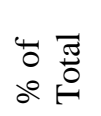 & $\bar{Q}$ & 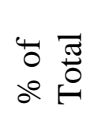 & $=$ & $\begin{array}{l}\text { II } \\
\sum \\
\sum\end{array}$ & 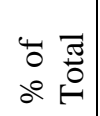 & $\bar{Q}$ & 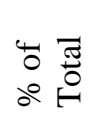 & $=$ & \\
\hline 0 & 1834.0 & 11.28 & 4595.96 & 11.36 & 101 & 696.0 & 12.91 & 1178.01 & 15.95 & 231 & 1091.6 & 9.43 & 1866.24 & 8.29 & 41 & 1263.7 & 9.18 & 2437.3 & 8.26 & 32 & 405 \\
\hline 5 & 1710.9 & 10.53 & 4795.95 & 11.85 & 40 & 761.8 & 14.13 & 1057.13 & 14.32 & 75 & 1036.6 & 8.96 & 1591.91 & 7.07 & 33 & 1573.35 & $\begin{array}{r}11.4 \\
2\end{array}$ & 3046.58 & 10.32 & 12 & 160 \\
\hline 8 & 1988.5 & 12.24 & 6078.52 & 15.02 & 86 & 771.2 & 14.30 & 1103.86 & 14.95 & 84 & 1083.5 & 9.36 & 2129.78 & 9.46 & 37 & 1566.02 & $\begin{array}{r}11.3 \\
7\end{array}$ & 3167.48 & 10.73 & 33 & 240 \\
\hline 10 & 2319.1 & 14.27 & 6242.32 & 15.43 & 127 & 788.9 & 14.63 & 1171.06 & 15.86 & 41 & 1629.6 & 14.08 & 2734.69 & 12.14 & 77 & 1866.4 & $\begin{array}{r}13.5 \\
5\end{array}$ & 3617.04 & 12.26 & 77 & 322 \\
\hline 12 & 2200.5 & 13.54 & 7100.09 & 17.55 & 81 & 1003.5 & 18.61 & 1439.38 & 19.49 & 21 & 1616.3 & 13.96 & 4037.12 & 17.93 & 42 & 2021.01 & 14.6 & 4776.91 & 16.19 & 56 & 200 \\
\hline $\begin{array}{l}15 \\
+\end{array}$ & 3331.1 & 20.50 & 10128.6 & 25.03 & 20 & - & - & - & - & - & 3163.1 & 27.33 & 6489.25 & 28.82 & 4 & 2863.21 & $\begin{array}{r}20.7 \\
9\end{array}$ & 6550.65 & 22.20 & 51 & 75 \\
\hline 풍 & $\begin{array}{l}\text { กิ } \\
\text { กิ } \\
\text { ஸู }\end{array}$ & $\begin{array}{l}8 \\
8 \\
8\end{array}$ & \begin{tabular}{l}
$n$ \\
$\infty$ \\
$\infty$ \\
\multirow{o}{+}{} \\
+
\end{tabular} & $\begin{array}{l}8 \\
8 \\
8\end{array}$ & 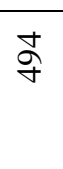 & ì & $\begin{array}{l}8 \\
8 \\
8\end{array}$ & $\begin{array}{l}\text { J } \\
\dot{+} \\
\stackrel{2}{\sim}\end{array}$ & $\begin{array}{l}8 \\
8 \\
8\end{array}$ & $\stackrel{+}{f}$ & $\begin{array}{l}0 \\
\stackrel{+}{ \pm} \\
= \\
=\end{array}$ & $\begin{array}{l}8 \\
8 \\
8\end{array}$ & $\begin{array}{l}n \\
\infty \\
a \\
\\
\text { ปn }\end{array}$ & $\begin{array}{l}8 \\
8 \\
8 \\
8\end{array}$ & $\stackrel{\infty}{\sim}$ & 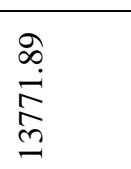 & $\begin{array}{l}8 \\
8 \\
8\end{array}$ & $\begin{array}{l}\text { पे } \\
\text { aे } \\
\stackrel{2}{2}\end{array}$ & $\begin{array}{l}8 \\
8 \\
8 \\
8\end{array}$ & $\stackrel{\infty}{\stackrel{\text { సे }}{2}}$ & 1494 \\
\hline
\end{tabular}

By and large, both, the standard of living and the income are rising with the increase in level of education in all sort of house hold occupations in rural Punjab (see Table 8) 
Table 9

Occupation-wise Levels of Education, MPCE and PCI of Individuals: Rural Punjab

\begin{tabular}{|c|c|c|c|c|c|c|c|c|c|c|c|c|c|c|c|c|c|c|c|c|c|}
\hline \multirow[b]{2}{*}{ 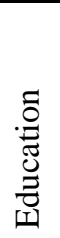 } & \multicolumn{5}{|c|}{ Ind. $\mathrm{O}_{\text {Agriculture }}$} & \multicolumn{5}{|c|}{ Ind. $\mathrm{O}_{\text {Wage Work }}$} & \multicolumn{5}{|c|}{ Ind. $\mathrm{O}_{\text {Own Work }}$} & \multicolumn{5}{|c|}{ Ind $\mathrm{O}_{\text {Service }}$} & \multirow{2}{*}{ 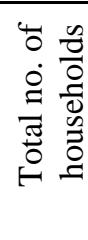 } \\
\hline & $\begin{array}{l}\text { U } \\
\sum \\
\sum\end{array}$ & $\begin{array}{l}\bar{\pi} \\
\stackrel{\pi}{0} \\
\stackrel{4}{0} \\
0 \\
0\end{array}$ & $\tilde{Q}$ & 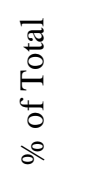 & $=$ & $\begin{array}{l}\text { U } \\
\sum \\
\sum\end{array}$ & $\begin{array}{l}\bar{\pi} \\
\stackrel{\tilde{U}}{0} \\
\stackrel{4}{0} \\
0 \\
0\end{array}$ & $\bar{Q}$ & 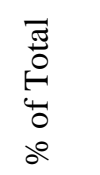 & $=$ & $\begin{array}{l}\text { U } \\
\sum \\
\sum\end{array}$ & $\begin{array}{l}\bar{\pi} \\
\stackrel{\tilde{0}}{0} \\
\stackrel{4}{0} \\
0 \\
0\end{array}$ & $\bar{Q}$ & $\begin{array}{l}\bar{\pi} \\
0 \\
0 \\
\text { U } \\
0 \\
0\end{array}$ & $=$ & $\begin{array}{l}\text { U1 } \\
巳 \\
\sum\end{array}$ & $\begin{array}{l}\bar{\pi} \\
0 \\
0 \\
4 \\
0 \\
0 \\
0\end{array}$ & $\bar{\Xi}$ & $\begin{array}{l}\bar{\pi} \\
0 \\
0 \\
4 \\
0 \\
0\end{array}$ & $=$ & \\
\hline 0 & 1796.1 & 10.61 & 4521.11 & 9.14 & 107 & 711.9 & 10.91 & 1200.32 & 12.36 & 232 & 1327.4 & 11.73 & 2452.28 & 10.53 & 29 & 955.91 & 7.65 & 1553.4 & 5.43 & 37 & 405 \\
\hline 5 & 1715.4 & 10.14 & 4864.1 & 9.84 & 40 & 769.0 & 11.79 & 1089.9 & 11.22 & 62 & 1078.0 & 9.52 & 1662.1 & 7.14 & 38 & 1070 & 8.56 & 1745.9 & 6.10 & 20 & 160 \\
\hline 8 & 2063.4 & 12.19 & 6413.04 & 12.97 & 72 & 798.1 & 12.24 & 1089.1 & 11.21 & 68 & 1139.2 & 10.06 & 2124.28 & 9.12 & 54 & 1374.1 & 10.99 & 3165.13 & 11.06 & 46 & 240 \\
\hline 10 & 2505.6 & 14.81 & 6664.09 & 13.48 & 107 & 1050.8 & 16.11 & 1723 & 17.74 & 41 & 1616.5 & 14.28 & 2775.48 & 11.92 & 83 & 1656.16 & 13.25 & 3470.37 & 12.13 & 91 & 322 \\
\hline 12 & 2199.4 & 13.00 & 7653.07 & 15.48 & 57 & 1450.3 & 22.23 & 2859.33 & 29.44 & 18 & 1686.0 & 14.89 & 3778.85 & 16.23 & 46 & 1915.84 & 15.33 & 4821.27 & 16.85 & 79 & 200 \\
\hline 15 & 3060.7 & 18.09 & 12097.36 & 24.46 & 25 & 1742.8 & 26.72 & 1750 & 18.02 & 1 & 2101.0 & 18.56 & 4576.95 & 19.66 & 19 & 2566.90 & 20.54 & 6214.45 & 21.72 & 47 & 92 \\
\hline $15+$ & 3582.7 & 21.17 & 7241.56 & 14.64 & 9 & - & - & - & - & - & 2372.9 & 20.96 & 5914.75 & 25.40 & 4 & 2960.70 & 23.69 & 7641.58 & 26.71 & 62 & 75 \\
\hline 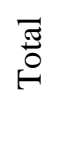 & 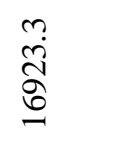 & $\begin{array}{l}8 \\
\stackrel{8}{8}\end{array}$ & 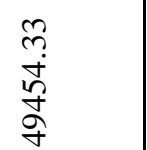 & $\begin{array}{l}8 \\
\stackrel{8}{8}\end{array}$ & $\bar{\ni}$ & 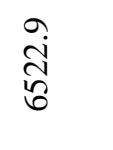 & $\begin{array}{l}8 \\
\stackrel{8}{8}\end{array}$ & $\begin{array}{l}n \\
\sigma \\
\sigma \\
\sigma\end{array}$ & $\begin{array}{l}8 \\
\stackrel{8}{8} \\
\stackrel{8}{0}\end{array}$ & $\underset{\mathcal{T}}{\mathcal{H}}$ & $\underset{\sim}{\stackrel{\Xi}{二}}$ & $\begin{array}{l}8 \\
\stackrel{8}{8}\end{array}$ & $\begin{array}{l}\hat{b} \\
\dot{+} \\
\text { ते } \\
\text { ते }\end{array}$ & $\begin{array}{l}8 \\
\stackrel{8}{8}\end{array}$ & $\stackrel{m}{\approx}$ & 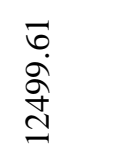 & $\begin{array}{l}8 \\
\dot{8}\end{array}$ & 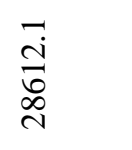 & $\begin{array}{l}8 \\
\dot{8}\end{array}$ & $\underset{\infty}{N}$ & $\stackrel{\Xi}{\text { I }}$ \\
\hline
\end{tabular}

Table 9 reveal that MPCE has rising trend with the increase of level of education of individuals in rural Punjab across all the occupations. As regarding the association of educational attainment with PCI, there is positive relationship between the two for individuals in all occupations. However, the PCI has

lowered for the individuals with the highest level of education in case of Agriculture and Wage work occupation; pertinently the number of respondents with the highest education level is very small in both these. 
1.4.1.1 Determinants of Poverty: Table 10 to Table 9 report the results of logistic regression equations run to identify impact of education upon poverty of the employed individuals in Punjab. We tried to break out the effect of education levels, experience and sector of job on the probability of being employed. The dependent variable is dichotomous in which the value 1 is assigned for the poor individual and 0 for the non-poor individual. In explanatory variables, educational variables are dummy variables. Every individual's education is classified into one of the seven categories viz. 0, 1$5,6-8,9-10,11-12,13-15$ and more than 15 . ' 0 ' education is left in the equation to serve as the reference category. Experience variable refers to individual's number of years in the job market. The employment of every individual is classified into two categories, namely 'Govt. Job' and 'Other than Govt. Job' (reference category in the equation). We have run logistic equation with enter method.

The odd ratios in the logistic regression results indicate the occurrence of any particular event. The odd ratios are defined as just two odds that are compared to determine whether one group has higher or lower odd ratios of binary outcome as compared to the reference category. A number, greater than one indicates a positive association between an independent variable and the dependent variable. While a number between zero and one indicates a negative association.

The overall results are demonstrated in Table 10 whereas separate residence-wise results are reported in Table 8.20 and Table 8.21. Gender-level results are set out in Table 13 for male and in Table 14 for female.

Chi-Square statistic indicates how well the independent variables affect the outcome or the dependent variable. As the P-values for the overall model fit statistic in all our analyses are less than the conventional 0.05 , it indicates that at least one of the independent variables contributes to the prediction of the outcome in all the models.

The classification tables show that the models correctly predict $76.97 \%, 80.81 \%, 74.16 \%, 76.89 \%$ and $78.75 \%$ of the cases for overall, urban, rural, male and female models respectively.

The area under the ROC curve measures discrimination, that is, the ability of the test to correctly classify poor and non-poor. Simply put, the area is a way to reduce ROC performance to a single value representing expected performance. The area under the ROC curve for our overall analysis is 0.800 (see Table 10) which is considered to be "good" at separating poor from non-poor. In our residence-wise analyses, the areas under the ROC curve are 0.823 and 0.778 respectively for urban and rural habitations which are considered respectively fair and good (see tables 11 and 12). Genderwise results produce values of 0.783 and 0.861 for male and female respectively, which are associated respectively with fair and good (see tables 13 and 14) ${ }^{12}$.

The overall results in Table 8.19 shows that the odd ratios of all variables are between zero and one that puts all the educational levels, experience and job sector in negative relation with the poverty status of the employed persons. The variables 1-5, 6-8, 9-10, 11-12, 13-15 and more than 15 level of education are decreasing the probability of being poor of employed persons by $38 \%, 107 \%, 164 \%$, $244 \%, 314 \%$ and $441 \%$ respectively as compared to the reference category of 'illiterate'.

Table 10: Logistic Regression Results, Dependent Variable: Probability of Being Poor (Overall)

\begin{tabular}{|l|l|}
\hline Dependent $Y$ & Poor $=1$, Non-poor $=0$ \\
\hline Method & Enter \\
\hline Sample size & 2844 \\
\hline Cases with $Y=0$ & $2081(73.17 \%)$ \\
\hline Cases with $Y=1$ & $763(26.83 \%)$ \\
\hline
\end{tabular}

\footnotetext{
${ }^{12}$ The procedure of Interpreting the Area Under the ROC Curve (AUC) is detailed in Chapter 7 entitled 'Education and Employment'.
} 


\section{Overall Model Fit}

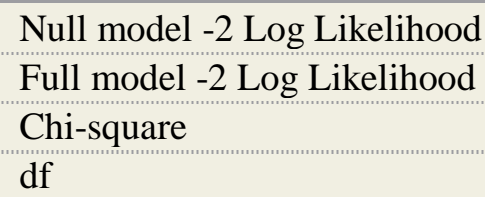

Significance level

\begin{tabular}{l|}
3307.826 \\
2623.636 \\
684.190 \\
\hline 8
\end{tabular}

Coefficients and Standard Errors

\begin{tabular}{|l|l|l|l|}
\hline Variable & Coefficient & Std. Error & $P$ \\
\hline Ed $_{1-5}$ & -0.3821 & 0.1555 & 0.0140 \\
\hline Ed $_{6-8}$ & -1.0737 & 0.1453 & $<0.0001$ \\
\hline Ed $_{9-10}$ & -1.6451 & 0.1390 & $<0.0001$ \\
\hline Ed $_{11-12}$ & -2.4451 & 0.1853 & $<0.0001$ \\
\hline Ed $_{13-15}$ & -3.1413 & 0.2810 & $<0.0001$ \\
\hline Ed $_{15+}$ & -4.4164 & 0.4699 & $<0.0001$ \\
\hline Exp & -0.03817 & 0.004189 & $<0.0001$ \\
\hline Emp & -1.0390 & 0.2449 & $<0.0001$ \\
\hline Constant & 0.9622 & & \\
\hline
\end{tabular}

Odds Ratios and 95\% Confidence Intervals

\begin{tabular}{|l|l|l|}
\hline Variable & Odds Ratio & $95 \%$ CI \\
\hline$E_{1-5}$ & 0.6824 & 0.5031 to 0.9257 \\
\hline $\mathrm{Ed}_{6-8}$ & 0.3418 & 0.2570 to 0.4544 \\
\hline $\mathrm{Ed}_{9-10}$ & 0.1930 & 0.1470 to 0.2534 \\
\hline $\mathrm{Ed}_{11-12}$ & 0.0867 & 0.0603 to 0.1247 \\
\hline $\mathrm{Ed}_{13-15}$ & 0.0432 & 0.0249 to 0.0750 \\
\hline $\mathrm{Ed}_{15+}$ & 0.0121 & 0.0048 to 0.0303 \\
\hline Exp & 0.9625 & 0.9547 to 0.9705 \\
\hline Emp $_{\mathrm{GJ}}$ & 0.3538 & 0.2190 to 0.5718 \\
\hline & &
\end{tabular}

Classification Table (cut-off value $\mathbf{p}=\mathbf{0 . 5}$ )

\begin{tabular}{|l|l|l|l|}
\hline Actual group & \multicolumn{2}{|l|}{ Predicted group } & Percent correct \\
\hline & 0 & 1 & \\
\hline $\mathrm{Y}=0$ & 1884 & 197 & $90.53 \%$ \\
\hline $\mathrm{Y}=1$ & 458 & 305 & $39.97 \%$ \\
\hline Percent of cases correctly classified & & $76.97 \%$ \\
\hline
\end{tabular}

ROC Curve Analysis

\begin{tabular}{|l|l|}
\hline Area under the ROC curve (AUC) & 0.800 \\
\hline Standard Error & 0.0103 \\
\hline $95 \%$ Confidence Interval & 0.785 to 0.815
\end{tabular}

Every next level of education has significantly lower likelihood of being poor vis-à-vis illiterates and this trend is seen in the results of equations run for urban \& rural area and for male \& female gender. However, primary level education is not contributing significantly in urban habitation and for males for decreasing the probability of being poor (see tables 11,12, 13 and 14). 
Table 11: Logistic Regression Results, Dependent Variable: Probability of Being Poor (Urban)

\begin{tabular}{|l|l|}
\hline Dependent $Y$ & Poor $=1$, Non-poor $=0$ \\
\hline Method & Enter \\
\hline Sample size & 1350 \\
\hline Cases with $Y=0$ & $1046(77.48 \%)$ \\
\hline Cases with $Y=1$ & $304(22.52 \%)$ \\
\hline
\end{tabular}

\section{Overall Model Fit}

\begin{tabular}{l|l}
\hline Null model -2 Log Likelihood & 1440.160 \\
\hline Full model -2 Log Likelihood & 1104.328 \\
\hline Chi-square & 335.832 \\
\hline df & 8 \\
\hline Significance level & $P<0.0001$
\end{tabular}

Coefficients and Standard Errors

\begin{tabular}{|l|l|l|l|}
\hline Variable & Coefficient & Std. Error & $P$ \\
\hline Ed $_{1-5}$ & -0.3318 & 0.2657 & 0.2118 \\
\hline$E_{6-8}$ & -1.1660 & 0.2519 & $<0.0001$ \\
\hline$E_{9-10}$ & -1.5664 & 0.2310 & $<0.0001$ \\
\hline$E_{11-12}$ & -2.5115 & 0.2870 & $<0.0001$ \\
\hline$E_{13-15}$ & -3.0050 & 0.3493 & $<0.0001$ \\
\hline Ed $_{15+}$ & -4.2304 & 0.5009 & $<0.0001$ \\
\hline Exp & -0.03425 & 0.007333 & $<0.0001$ \\
\hline Emp & -1.0643 & 0.3071 & 0.0005 \\
\hline Constant & 1.0350 & & \\
\hline & & & \\
\hline
\end{tabular}

Odds Ratios and 95\% Confidence Intervals

\begin{tabular}{|l|l|l|}
\hline Variable & Odds Ratio & $95 \%$ CI \\
\hline Ed $_{1-5}$ & 0.7177 & 0.4264 to 1.2080 \\
\hline $\mathrm{Ed}_{6-8}$ & 0.3116 & 0.1902 to 0.5105 \\
\hline $\mathrm{Ed}_{9-10}$ & 0.2088 & 0.1328 to 0.3284 \\
\hline $\mathrm{Ed}_{11-12}$ & 0.0811 & 0.0462 to 0.1424 \\
\hline $\mathrm{Ed}_{13-15}$ & 0.0495 & 0.0250 to 0.0982 \\
\hline $\mathrm{Ed}_{15+}$ & 0.0145 & 0.0054 to 0.0388 \\
\hline Exp & 0.9663 & 0.9525 to 0.9803 \\
\hline Emp $_{\text {GJ }}$ & 0.3450 & 0.1890 to 0.6298 \\
\hline
\end{tabular}

Classification Table (cut-off value $\mathbf{p}=\mathbf{0 . 5}$ )

\begin{tabular}{|l|l|l|l|}
\hline Actual group & \multicolumn{2}{|l|}{ Predicted group } & Percent correct \\
\hline & 0 & 1 & \\
\hline $\mathrm{Y}=0$ & 979 & 67 & $93.59 \%$ \\
\hline $\mathrm{Y}=1$ & 192 & 112 & $36.84 \%$ \\
\hline Percent of cases correctly classified & & $80.81 \%$ \\
\hline
\end{tabular}

ROC curve analysis

Area under the ROC curve (AUC)

Standard Error

0.823

95\% Confidence Interval 
Experience has negative coefficient sign and with the increase of one year in experience we observe decline of $3.8 \%$ in the likelihood of being poor of individuals in overall regression equation (Table 10). The contribution of experience in decreasing poverty is higher in rural area and for females than in urban area and for males (see tables 11,12, 13 and 14).

Overall, as compared to non-govt. job, being in government job decreases the probability of being poor by $103 \%$ (Table 8.19). In declining the likelihood of being poor, the govt. job is more beneficial in rural areas than in urban area and for females than for males (see tables 11,12,13 and 14).

Table 12: Logistic Regression Results, Dependent Variable:

Probability of Being Poor (Rural)

\begin{tabular}{|l|l|}
\hline Dependent $Y$ & Poor $=1$, Non-poor $=0$ \\
\hline Method & Enter \\
\hline Sample size & 1494 \\
\hline Cases with Y=0 & $1035(69.28 \%)$ \\
\hline Cases with $Y=1$ & $459(30.72 \%)$ \\
\hline
\end{tabular}

\section{Overall Model Fit}

Null model -2 Log Likelihood
Full model -2 Log Likelihood
Chi-square
DF
Significance level

1843.194
1507.631
335.563
8
$P<0.0001$

\section{Coefficients and Standard Errors}

\begin{tabular}{|l|l|l|l|}
\hline Variable & Coefficient & Std. Error & $\mathrm{P}$ \\
\hline $\mathrm{Ed}_{1-5}$ & -0.4825 & 0.1975 & 0.0146 \\
\hline $\mathrm{Ed}_{6-8}$ & -1.0644 & 0.1814 & $<0.0001$ \\
\hline $\mathrm{Ed}_{9-10}$ & -1.8016 & 0.1841 & $<0.0001$ \\
\hline $\mathrm{Ed}_{11-12}$ & -2.4666 & 0.2530 & $<0.0001$ \\
\hdashline $\mathrm{Ed}_{13-15}$ & -3.7721 & 0.6047 & $<0.0001$ \\
\hdashline $\mathrm{dd}_{15+}$ & -20.9959 & 2222.5435 & 0.9925 \\
\hdashline $\operatorname{Exp}$ & -0.04044 & 0.005191 & $<0.0001$ \\
\hline Emp & -1.1304 & 0.4173 & 0.0067 \\
\hline Constant & 0.9641 & & \\
\hline & & & \\
\hline
\end{tabular}

Odds Ratios and 95\% Confidence Intervals

\begin{tabular}{|l|l|l|}
\hline Variable & Odds Ratio & $95 \%$ CI \\
\hline Ed $_{1-5}$ & 0.6173 & 0.4191 to 0.9091 \\
\hline $\mathrm{Ed}_{6-8}$ & 0.3450 & 0.2417 to 0.4922 \\
\hline $\mathrm{Ed}_{9-10}$ & 0.1650 & 0.1150 to 0.2368 \\
\hline $\mathrm{Ed}_{11-12}$ & 0.0849 & 0.0517 to 0.1394 \\
\hline $\mathrm{Ed}_{13-15}$ & 0.0230 & 0.0070 to 0.0753 \\
\hline $\operatorname{Ed}_{15+}$ & 0.0000 & 0.0000 to 0.0000 \\
\hline $\operatorname{Exp}$ & 0.9604 & 0.9506 to 0.9702 \\
\hline Emp $_{\mathrm{GJ}}$ & 0.3229 & 0.1425 to 0.7316 \\
\hline
\end{tabular}


Classification Table (cut-off value $p=0.5$ )

\begin{tabular}{|l|l|l|l|}
\hline Actual group & \multicolumn{2}{|l|}{ Predicted group } & Percent correct \\
\hline & 0 & 1 & \\
\hline $\mathrm{Y}=0$ & 924 & 111 & $89.28 \%$ \\
\hline $\mathrm{Y}=1$ & 275 & 184 & $40.09 \%$ \\
\hline Percent of cases correctly classified & $74.16 \%$ & \\
\hline
\end{tabular}

ROC Curve Analysis

Area under the ROC curve (AUC)

Standard Error

0.778

95\% Confidence Interval

0.756 to 0.798

Table 8.13: Logistic Regression Results, Dependent Variable: Probability of Being Poor (Male)

\begin{tabular}{|l|l|}
\hline Dependent $\mathrm{Y}$ & Poor $=1$, Non-poor $=0$ \\
\hline Method & Enter \\
\hline Sample size & 2298 \\
\hline Cases with $\mathrm{Y}=0$ & $1723(74.98 \%)$ \\
\hline Cases with $\mathrm{Y}=1$ & $575(25.02 \%)$ \\
\hline
\end{tabular}

Overall Model Fit

\begin{tabular}{|l|l|}
\hline Null model -2 Log Likelihood & 2585.590 \\
\hline Full model -2 Log Likelihood & 2117.115 \\
\hline Chi-square & 468.476 \\
\hline df & 8 \\
\hline Significance level & P $<0.0001$ \\
\hline
\end{tabular}

Coefficients and Standard Errors

\begin{tabular}{|l|l|l|l|}
\hline Variable & Coefficient & Std. Error & $\mathrm{P}$ \\
\hline $\mathrm{Ed}_{1-5}$ & -0.2523 & 0.1715 & 0.1412 \\
\hline $\mathrm{Ed}_{6-8}$ & -0.9406 & 0.1624 & $<0.0001$ \\
\hline $\mathrm{Ed}_{9-10}$ & -1.5300 & 0.1541 & $<0.0001$ \\
\hline $\mathrm{Ed}_{11-12}$ & -2.4086 & 0.2127 & $<0.0001$ \\
$\mathrm{Ed}_{13-15}$ & -3.4044 & 0.3818 & $<0.0001$ \\
\hline $\mathrm{Ed}_{15+}$ & -4.3256 & 0.7285 & $<0.0001$ \\
\hline $\mathrm{Exp}$ & -0.03256 & 0.004518 & $<0.0001$ \\
\hline Emp & -1.3332 & 0.3255 & $<0.0001$ \\
\hline Constant & 0.6984 & &
\end{tabular}

Odds Ratios and 95\% Confidence Intervals

\begin{tabular}{|l|l|l|}
\hline Variable & Odds Ratio & $95 \%$ CI \\
\hline Ed $_{1-5}$ & 0.7770 & 0.5553 to 1.0874 \\
\hdashline $\mathrm{Ed}_{6-8}$ & 0.3904 & 0.2839 to 0.5367 \\
\hline $\mathrm{Ed}_{9-10}$ & 0.2165 & 0.1601 to 0.2929 \\
\hline $\mathrm{Ed}_{11-12}$ & 0.0899 & 0.0593 to 0.1365 \\
\hline $\mathrm{Ed}_{13-15}$ & 0.0332 & 0.0157 to 0.0702 \\
\hline $\mathrm{Ed}_{15+}$ & 0.0132 & 0.0032 to 0.0552 \\
\hline Exp & 0.9680 & 0.9594 to 0.9766 \\
\hline Emp $_{\mathrm{GJ}}$ & 0.2636 & 0.1393 to 0.4990 \\
\hline & &
\end{tabular}


Classification Table (cut-off value $p=0.5$ )

\begin{tabular}{|l|l|l|l|}
\hline Actual group & Predicted group & Percent correct \\
\hline & 0 & 1 & \\
\hline $\mathrm{Y}=0$ & 1597 & 126 & $92.69 \%$ \\
\hline $\mathrm{Y}=1$ & 405 & 170 & $29.57 \%$ \\
\hline Percent of cases correctly classified & & $76.89 \%$ \\
\hline
\end{tabular}

ROC Curve Analysis

\begin{tabular}{l|l}
\hline Area under the ROC curve (AUC) & 0.783 \\
\hline Standard Error & 0.0121 \\
\hline 95\% Confidence Interval & 0.766 to 0.800
\end{tabular}

Table 8.14: Logistic Regression Results, Dependent Variable: Probability of Being Poor (Female)

\begin{tabular}{|l|l|}
\hline Dependent $Y$ & Poor $=1$, Non-poor $=0$ \\
\hline Method & Enter \\
\hline Sample size & 546 \\
\hline Cases with $Y=0$ & $358(65.57 \%)$ \\
\hline Cases with $Y=1$ & $188(34.43 \%)$ \\
\hline
\end{tabular}

\section{Overall Model Fit}

\begin{tabular}{l|l}
\hline Null model -2 Log Likelihood & 703.096 \\
\hline Full model -2 Log Likelihood & 468.114 \\
\hline Chi-square & 234.982 \\
\hline df & 8 \\
\hline Significance level & $\mathrm{P}<0.0001$ \\
\hline
\end{tabular}

Coefficients and Standard Errors

\begin{tabular}{|l|c|c|c|}
\hline \multicolumn{1}{|c|}{ Variable } & Coefficient & Std. Error & $\mathrm{P}$ \\
\hline $\mathrm{Ed}_{1-5}$ & -0.6723 & 0.3831 & 0.0793 \\
\hline $\mathrm{Ed}_{6-8}$ & -1.2076 & 0.3464 & 0.0005 \\
\hline $\mathrm{Ed}_{9-10}$ & -1.4011 & 0.3736 & 0.0002 \\
\hline $\mathrm{Ed}_{11-12}$ & -2.0470 & 0.4069 & $<0.0001$ \\
\hline $\mathrm{Ed}_{13-15}$ & -2.6580 & 0.4645 & $<0.0001$ \\
\hline $\mathrm{Ed}_{15+}$ & -4.8392 & 0.6413 & $<0.0001$ \\
\hline Exp & -0.04480 & 0.01307 & 0.0006 \\
\hline Emp & -0.8455 & 0.4055 & 0.0371 \\
\hline Constant & 1.5394 & & \\
\hline
\end{tabular}

Odds Ratios and 95\% Confidence Intervals

\begin{tabular}{|l|c|c|}
\hline \multicolumn{1}{|c|}{ Variable } & Odds Ratio & $95 \%$ CI \\
\hline $\mathrm{Ed}_{1-5}$ & 0.5105 & 0.2409 to 1.0817 \\
\hline $\mathrm{Ed}_{6-8}$ & 0.2989 & 0.1516 to 0.5894 \\
\hline $\mathrm{Ed}_{9-10}$ & 0.2463 & 0.1184 to 0.5123 \\
\hline $\mathrm{Ed}_{11-12}$ & 0.1291 & 0.0582 to 0.2867 \\
\hline $\mathrm{Ed}_{13-15}$ & 0.0701 & 0.0282 to 0.1742 \\
\hline $\mathrm{Ed}_{15+}$ & 0.0079 & 0.0023 to 0.0278 \\
\hline $\operatorname{Exp}$ & 0.9562 & 0.9320 to 0.9810 \\
\hline Emp $_{\mathrm{GJ}}$ & 0.4294 & 0.1939 to 0.9507 \\
\hline
\end{tabular}


Classification Table (cut-off value $p=0.5$ )

\begin{tabular}{|c|c|c|c|}
\hline Actual group & \multicolumn{2}{|c|}{ Predicted group } & Percent correct \\
\hline & 0 & 1 & \\
\hline$Y=0$ & 297 & 61 & $82.96 \%$ \\
\hline$Y=1$ & 55 & 133 & $70.74 \%$ \\
\hline Percent of cases correctly classified & $78.75 \%$ \\
\hline \multicolumn{2}{|c|}{ ROC Curve Analysis } \\
\hline Area under the ROC curve (AUC) & 0.861 \\
\hline Standard Error & 0.0183 \\
\hline 95\% Confidence Interval & 0.829 to 0.889 \\
\hline
\end{tabular}

\subsection{Summary and Conclusion}

Using data from the primary survey of 1520 households from rural and urban habitations collected over 2008-10, this chapter estimates the effect of education on poverty in Punjab. Analysis has been done at the household as well as the individual level. Apart from making simple comparisons between standard of living, income and education level, logistic regression has been employed to sort out the determinants of poverty. Standard of living and PCI are positively associated with education level at the household as well as individual level, implying improvement in educational attainments reduces the likelihood of being poor.

The results of logistic regression are in line with the generally accepted theory that educational attainment is pivotal in declining the incidence of poverty and should be given due consideration in implementing poverty alleviation programs. Our results show that education attainment has a negative impact on poverty. The consistent increase in the likelihood of escaping poverty of a person with the increase in educational level means that as educational achievement increases the probability of a person to fall in absolute poverty declines. The attainment of education increases the earning potentials of individuals, and as such enhanced earnings help them escape poverty. Experience is also negatively related with poverty status. Obviously, as the experience of a person in the field of work grows so does his /her expertise, which consequently enhances his/her demand in the job market causing him/her earn more.

\subsection{Policy Implications}

The relationship between education and poverty reduction is very clear: educated people have higher income earning potential, and are better able to improve the quality of their lives. But poverty is both a cause and an effect of insufficient access to or completion of quality education. Children of poor families are less likely to enroll in and complete schooling because of the associated costs of attending school, even when it is provided free. The cost of uniforms, books \& stationery supplies, and transportation may well be beyond the means of a poor family, especially when the family has several children of school age. This means that choices have to be made, and the choice is often to drop out of school. And as poor children who are enrolled grow older, the opportunity cost (their lost labor and the foregone income it may entail) becomes greater, thus increasing the likelihood of abandoning school. Dropping out of school because of poverty virtually guarantees perpetuation of the poverty cycle since the income-earning potential of the child is reduced. Lack of education perpetuates poverty, and poverty constrains access to schooling.

As this study, like many other studies, has shown that educational attainment is a critical determinant of the incidence of poverty, education should be given due consideration in implementing poverty reduction programs.

\section{References}

Ahmad, A., Hossain, M., and L., Bose, M. L. (2005). Inequality in the Access to Secondary Education and Rural Poverty in Bangladesh: An Analysis of Household and School Level Data. (Working Paper No. 2005:36). Department of Economics. Lund, Sweden: Lund University. Retrieved on 27-8-2011 from http://ideas.repec.org/p/hhs/ lunewp/2005_036.html. 
Arif, G.M., Saqib, U.S., and G.M. Zahid (1999). Poverty, Gender, and Primary School Enrolment in Pakistan. The Pakistan Development Review, 38 (4), 979-992.

Awan, M. S., Malik, N., Sarwar, H. and Waqas, M. (2011). Impact of Education on Poverty Reduction. International Journal of Academic Research, 3 (1) Jan. Part II, 659-664.

Chaudhry, I.S. (2009). Poverty Alleviation in Southern Punjab (Pakistan): An Empirical Evidence from the Project Area of Asian Development Bank. International Research journal of Finance and Economics, Issue.23, 23-32. Retrieved on 27-8-2011 from http://www.eurojournals.com/irjfe_23_02.pdf. [

Chaudhry, I. M. and Rahman, S. U. (2009). The Impact of Gender Inequality in Education on Rural Poverty in Pakistan: An Empirical Analysis. European Journal of Economics, Finance and Administrative Sciences, Issue 15, 174-188. Retrieved on 27-8-2011 from http://www.eurojournals.com/EJEFAS.htm.

Bramley, G. and Karley K. N. (2005). Home-Ownership, Poverty and Educational Achievement: Individual, School and Neighbourhood Effects. CRSIS Research Report. www.crsis.hw.ac.uk.

Mathur, A. and Mamgain, R. P. (2002). Technical Skills, Education and Economic Development in India. The Indian Journal of Labour Economics, 45 (4), 1015-1046.

Njong, A. M. (2010). The Effects of Educational Attainment on Poverty Reduction in Cameroon. Journal of Education Administration and Policy Studies, 2 (1), 001-008. Available online at http:/www.academicjournals.org/JEAPS.

Okojie, C.E.E. (2002). Gender and Education as Determinants of Household Poverty in Nigeria. (Discussion Paper No. 2002/37). World University for Development Economics Research (WIDER). Retrieved on 27-8-2011 from www.wider.unu.edu/.

Planning Commision (2007). Poverty estimates for 2004-05. Government of India. Retrieved on 26-22011 from http://en.wikipedia.org/wiki/Poverty_in_India\#tite_note-Poverty_estimates_for_2004-052\#cite_note-Poverty_estimates_for_2004-05-2

Population Bulletin (2001, March). A Publication of Population Reference Bureau. 56 (1).

Tilak, J. B. G. (1994). Education for Development in Asia. New Delhi: Sage Publications India Pvt. Ltd. [

Tilak, J. B.G. (2001). Education and Development: Lessons from Asian Experience. Indian Social Science Review, 3 (2), 219-266. 